\title{
Prospects for using foreign experience in the organization of executive power in Russia
}

\author{
Vitaly Goncharov ${ }^{1, *}$, Tatiana Mikhaleva ${ }^{2}$, Grigory Vasilevich $^{2}$, Sergey Balashenko ${ }^{2}$, Jacek \\ Zalesny ${ }^{3}$, and Artem Pukhov ${ }^{2}$ \\ ${ }^{1}$ Kuban State Agrarian University Named after I.T. Trubilin, Russia \\ ${ }^{2}$ Belarusian State University, Republic of Belarus \\ ${ }^{3}$ University of Warsaw, Republic of Poland
}

\begin{abstract}
This article is devoted to the analysis of problems and prospects of using in the Russian Federation the positive experience of the formation and functioning of the executive branch abroad. The paper substantiates the need to implement successful developments in the system of public administration received in other countries into the Russian system of executive power. The paper assesses the opportunities, prospects and risks of using the positive experience of the formation and functioning of the executive branch abroad. The authors prove that in the process of optimizing the executive power system in the Russian Federation, it is necessary to use foreign positive experience in the formation and functioning of government bodies (executive power). However, this experience should be evaluated according to the system of criteria justified in this scientific article.
\end{abstract}

\section{Introduction}

The Institute of Executive Power in the Russian Federation is widely analyzed in the scientific works of N.Yu. Khamaneva, O.E. Kutafin, V.V. Grib, L.Yu. Grudtsyna, V.E. Chirkin and several other authors. These works provide the basis for the analysis of the theoretical content of the executive branch in relation to its social essence. However, the share of researches that highlight the problems and prospects of using the positive experience in the formation and functioning of the system of executive power (public administration) abroad in the Russian Federation is extremely small. In this regard, the main purpose of this research is a comprehensive study of the problems and prospects of using in the Russian Federation the positive experience of the formation and functioning of the system of executive power (public administration) abroad, in order to expand and clarify the conceptual and categorical apparatus of the science of constitutional law in the sphere of executive power, having formed a holistic concept of the optimal organization and implementation of executive power in Russia, and subject to follow - the regulatory framework of formation and functioning of the system of executive power abroad and in the Russian Federation, as well as scientific views on the problems and prospects of

\footnotetext{
* Corresponding author: niipgergo2009@mail.ru
} 
Russia's positive experience of formation and functioning of the system of executive power (governance) abroad.

\section{Materials and Methods}

This article in the process of cognition of state-legal phenomena were used: a) General scientific methods (formal-logical, systemic, structural-functional, concrete-historical); b) General logical methods of theoretical analysis (analysis, synthesis, generalization, comparison, abstraction, analogy, modeling, etc.); c) private scientific methods (technical and legal analysis, specification, interpretation, etc.) (Zalesny, Goncharov, 2019: 129-142; Zalesny et all., 2019: 51-61; Zalesny, Goncharov, 2020a: 1-6; Goncharov et all., 2020a, 7890; Goncharov et all., 2020b, 93-106; Moros, Goncharov, 2020, 114-128; Zalesny, Goncharov, 2020b: 1-10).

\section{Results and Discussion}

The construction of an optimal system of executive power in the Russian Federation must be carried out taking into account the analysis of the positive experience in building and functioning the public administration system in foreign countries.

It seems that as the main criteria for assessing the effectiveness of the formation and functioning of the executive power system in a single state, the following can be distinguished:

1) what is the ideological basis of statehood in a given country, how much does it correspond to the prospects of preserving and developing statehood, the sovereignty of the state, its independence and territorial integrity; (Avakyan, 2019: 18-21; Kiseleva, 2018: 6169)

2) to what extent the functioning of the executive power system ensures the progressive development of the state in socio-economic terms (this level of progressive development of the state should be assessed on the basis of analysis of indicators of the socio-economic development indices of the state, for example, the growth of the gross domestic product (gross national product) of a country, its gross domestic income, labor productivity, capital productivity, etc.); (Kalinin, 2020: 14-23; Maslovskaya, 2020: 46-52)

3 ) the extent to which public administration in the country is carried out by the executive authorities at their own discretion on the basis of the will and will of the people and in their interests (this should be assessed on the basis of indicators of independence, stability and independence of the state executive system from illegal internal influence and negative external influences, taking into account the analysis of the degree of development of the introduction of direct democracy institutions in the country (Komarova, 2006: 5-10), under which in modern legal science they have "methods and means of directly exercising power by the people or part thereof, excluding the transfer of power to any bodies or persons" (Dmitriev, Komarova, 1995, 52-56), as well as their reality);

4) the extent to which the system of executive power in the state is structured, how much the formation and functioning of the system of executive power in the country is carried out on the basis of legal principles laid down in the constitution of the country and its current legislation (that is, how legal is the public administration system and what is its place in the state mechanism of a given country);

5) to what extent the organization and activity of the executive power system in the state creates the conditions and contributes to the realization by citizens of the state of their constitutionally and legislatively fixed rights, freedoms and interests, corresponds to the interests and real needs of the majority of the population (that is, how much the public 
administration system in the country is not only legal, but also legitimate) (Chirkin, 1995: 65-73);

6) how stable is the system of executive power in the state against external and internal influences, competitive in the era of increased interstate competition resulting from the globalization of mankind (balanced);

7) how efficiently the executive power system in the state spends budget funds and provides public services to the population (the main indicator of this is the achievement of a high level of executive discipline) and what are the criteria and mechanisms for evaluating and self-evaluating its effectiveness and effectiveness.

However, the use of positive foreign experience in the formation and functioning of the executive system in the process of optimizing the executive system in the Russian Federation is complicated by a number of problems.

First of all, the lack of elaboration and consolidation in the Constitution of Russia and the current legislation of the ideological basis of Russian statehood makes it difficult to choose a successful public administration system abroad, which can be taken as a basis for optimizing the executive system in our country, so the unity of form and content of the economic basis must be observed state and its socio-political superstructure, of which the public administration system is a part (in particular, lei, tasks and principles of the formation of the functioning and optimization of the public administration system, as well as the methods, methodologies and technologies for its optimization).

Significant difficulties for introducing the positive experience of the formation and functioning of the executive system are the uncertainty and disharmony of the socioeconomic paradigm of the development of Russian statehood in the framework of existing major civilization projects. In addition, the executive power system has been formed in Russia relatively recently, and the organization and activity of the state power as a whole is still influenced by the stereotypes that developed during our country's existence as part of the Soviet civilization project, which enshrined the sovereignty of the councils and denied the possibility of implementing the principle of separation of powers (in particular, this concerns a hypertrophic concentration of power in the hands of government bodies directly, with a large secondary role of the legislative and judicial branches).

Certain problems in the perception and implementation of positive foreign experience in the organization and activities of government are also caused by the difference in the content and availability of a real mechanism for putting into practice the principles of the formation and functioning of the executive branch of the Russian Federation and the main modern developed foreign countries. So, many of the principles of the organization and activities of the executive system (for example, the participation of citizens in the management of public affairs, transparency, ethics and professionalism in the work of executive bodies and their officials) are formally enshrined in existing Russian legislation, similar to foreign countries, but not supported in contrast, stable centuries-old forming mechanisms of real embodiment and protection from the arbitrariness of power.

Significant difficulties in the perception of foreign experience in organizing and operating government bodies are also caused by the difference between Russia and other countries due to a number of cultural, historical, and socio-economic features.

An important role in the possibility of perception and implementation in our country of positive foreign experience in the functioning of the public administration system is played by the global increase in the level of corruption in the ranks of both the executive power system in the Russian Federation and other branches of state power and local government in the country. The scope of the corruption component in the state apparatus is an order of magnitude ahead of not only the developed capitalist states of our time (in particular, the USA and the countries of the European Union), but also significantly exceeds the level of corruption in socialist states (for example, PRC), as well as a number of the most successful 
states with economies in transition that have reached a high level of human development index (in particular, the Republic of Belarus) (Research, 2006).

A kind of typo on the possibility of introducing successful foreign experience in the formation and functioning of the public administration system is also imposed by the imbalance in its perception by the masses, who for the most part believe in the special role of Russia in the modern world, suggesting that the country chooses its own, non-westoriented development path (Messianic aspect), and the state elite of the country that denies it.

However, as the experience of modernizing the public administration system at the turn of the 20th-21st centuries (in particular, in the PRC and the Republic of Belarus) shows, an adequate assessment of the positive foreign experience in the formation and functioning of the executive power system, its timely use in the processes of optimizing the state apparatus allows significant success in restoration and strengthening of manageability of the country, carrying out large-scale measures to modernize its economy (Goncharov, 2014: 104-107; Goncharov, 2011: 127-131; Vasilevich et all., 2019: 85-92).

The use in the Russian Federation of positive experience in the formation and functioning of the executive system abroad, taking into account the optimization processes being carried out in a number of countries, will allow, in particular: 1) to decide on the issue of optimizing the executive system in our country in the framework of existing civilization projects, or to implement it in as an independent civilization project; 2) to avoid typical mistakes in the organization and activities of government, minimizing the negative consequences of the ongoing optimization; 3) to use exclusively approved methods, methodology and technologies in the process of optimizing the system of executive power in the country, the positiveness of which is proved by the practice of the formation and functioning of public administration systems in a number of foreign states; 4) carry out optimization processes in dynamics, taking into account updated information based on a constant analysis of the processes of modernization of public administration systems abroad; 5) create a more effective mechanism for monitoring and evaluating the effectiveness and efficiency of the organization and activities of the system of executive authorities and their officials (especially in terms of the provision of public services to the public).

Considering the above criteria for assessing the effectiveness of the formation and functioning of the executive system, we will consider the experience of its organization and the activities of a number of foreign states that have achieved some success in reforming the public administration system and modernizing the economy (the Republic of Belarus and the PRC), determining the prospects for implementing this experience in the Russian Federation. This choice is not accidental, since China is the world economic and political leader personifying the "tomorrow" of the global world order, and an analysis of the particularities of the formation and functioning of the executive power system in the Republic of Belarus is necessary due to the fact that this country is the most culturally and ethnically close state for Russia, its system of state power in its construction was largely based on the Russian model, but at the same time, this country is a leader among the CIS countries in a number of socio-economic indicators and the human development index.

It seems that quite large successes in building an effective system of executive power were achieved on the territory of the former USSR in the Republic of Belarus (Nechkin, 2014: 52-55).

First, in the Republic of Belarus the Constitution, unlike Article 13 of the Constitution of the Russian Federation does not contain a direct denial of the possibility of forming and establishing the ideological foundations of the state (the state ideology). Thus, Article 4 of the Belarusian Constitution provides certain guarantees to the society that prevent certain political parties, religious and other public associations and social groups to impose their 
ideology of citizens as required (Constitution, 2020a), but here we are talking more about the fact that no ideology, formed separate social groups cannot be established as obligatory for citizens of the Republic of Belarus except the government. This fact has been reaffirmed in policy statements of the President of Belarus, emphasized the need and importance of formation of the state ideology in the country, the legal basis of which is the Constitution of the Republic of Belarus (Lukashenko, 2003: 3-68). Analysis of the Article 4 of the Constitution shows that the conceptual basis of the state ideology in the country is a democracy, carried out on the basis of diversity of political institutions, ideologies and opinions (Constitution, 2020a). State ideology in Belarus fully corresponds to the prospects of preservation and development of Belarusian statehood, its sovereignty, independence and territorial integrity. Thus, Article 2 of the Constitution not only enshrines the highest values and goals of society and the state of man, his rights, freedoms and guarantees for their implementation, but also the mutual responsibility of state and citizen in terms of creating state conditions for free and worthy development of the personality and the scrupulous fulfillment of the duties imposed on him by the Constitution.

It seems that the Russian Federation should take advantage of the experience of the Republic of Belarus in the formation and consolidation of state ideology in the current legislation, which will be a kind of strategic program for the formation and functioning of the public administration system in our country. In accordance with the conceptual framework enshrined in it, the optimization of the executive power system in Russia will be carried out.

Secondly, the Republic of Belarus is the only one in the post-Soviet space that has achieved gross domestic product growth of up to $10 \%$ annually since 1997 (Website, 2020), and in comparable prices per capita in 2010 it has every chance of reaching the first place among the CIS countries on this indicator, ahead of the Russian Federation. Moreover, taking into account the fact that in the gross domestic product of Russia more than $50 \%$ are products of the fuel and energy complex and extractive industries, the price of which since the late $90 \mathrm{~s}$ has increased by an average of 6-7 times (this growth was of a conjunctural nature, and foreign exchange earnings from the sale of minerals were not directed by the leadership of the Russian Federation to modernize its economy), as well as a large share of the service sector (unlike the Republic of Belarus), it is obvious that the economy of the Republic of Belarus is he most innovative, with a high share of engineering products and other manufacturing industries, within the framework of the CIS. Impressive successes were achieved in the Republic of Belarus both in increasing labor productivity in industry and agriculture, as well as in terms of capital productivity of enterprises and the economy as a whole (in similar sectors in the Russian Federation, these indicators are 1,3-1,7 times lower). In addition, taking into account the latest changes in the procedure for calculating statistical data in Russia, the data of official statistics in our country, according to a number of economists, are in great doubt (Personal, 2020).

In the Republic of Belarus, the executive branch carries out effective economic management, competently financing the real sector of the economy from the republican budget. A large number of agro-cities and towns with modern infrastructure have been built, the state has bought back from private individuals the shares of most competitive enterprises and is the holder of their controlling stake. It seems necessary for our country to stop concentrating financial reserves in doubtful securities abroad by investing in "foreign" economies, and to take advantage of the experience of Belarus in supporting and developing the real sector of the economy with all available financial reserves and opportunities.

Thirdly, the system of executive power in the Republic of Belarus is distinguished by enviable constancy. Since 1994 (almost 2 years after independence) the President of the country has been permanently A.G. Lukashenko (from the moment this post appeared in the 
power system of the Republic). The executive branch in the Republic of Belarus is extremely independent and, in determining its development, ignores any attempts at outside interference (for example, from the IMF, USA) (Matusevich, 1998: 19-25).

State administration in the Republic of Belarus is carried out by executive authorities headed by the President of the country and the Government at their own discretion on the basis of the will and will of the people and in their interests. The head of state repeatedly appealed for support directly to the people (including the carrying out of the next stages of constitutional reform), and the people trusted him in national referenda (both on changes to the Constitution of the Republic of Belarus and on the extension of presidential powers) (Maslovskaya, 2004; Parechina, 2002: 22-28). The popularity rating of the President of the country steadily exceeds $70-80 \%$, allowing him to make decisions that are often unpopular, but extremely useful for the state economy (Website, 2020).

By the degree of development of the introduction of institutions of direct democracy in the formation and functioning of executive bodies, the Republic of Belarus is the undisputed leader among the CIS countries. In addition to their traditional varieties (referendum, elections, at which an official directly exercising state power is directly elected), the head of state actively uses procedures for popular discussion (Report, 2020). The Constitution of the Republic of Belarus enshrines such institutions of direct democracy as petitions (appeals) of citizens (Article 40 defines their personal and collective appeals of citizens and obliges state bodies and their officials not only to consider them, but also to give substantive answers within the time limit specified by law, or provide a written reasoned refusal to consider submitted applications); the right of people's law-making initiative (Article 99 enshrines the right of legislative initiative to a group of citizens, the number of at least 50 thousand people) (Constitution, 2020a). Moreover, these institutions of direct democracy are real and are used in the political practice of the Republic with enviable constancy.

The stability of the executive power system in the Republic of Belarus is also manifested in the low level of corruption in public administration; in the absence of such negative phenomena as cronyism, embezzlement in it (Vasilevich, 2012: 22-26). Officials of executive bodies are not agents of influence of the Western special services, they do not contribute to the "washing out" of funds from the Republic of Belarus. The country has a fairly small number of officials (per capita, this figure is 2,2 times less than in Russia), a high level of professionalism and performing discipline, and the funds of the republican budget are effectively used (Website, 2020).

It seems necessary to take advantage of the experience of Belarus in strengthening the executive system, combating corruption, embezzlement, cronyism, lobbying civil servants for the interests of financial-oligarchic groups (domestic and foreign).

Fourthly, the formation and functioning of the system of executive power in the Republic of Belarus is carried out on the basis of a number of legal principles laid down in the Constitution of the country and its current legislation. Among them, one can single out such principles of organization and activity of government bodies as separation of powers; election; legality; democracy; an effective combination of centralism and decentralization; publicity and responsibility; professionalism and compliance with high ethical principles in work; collegiality and one-man management.

Of particular interest for the use of the executive power system in the optimization process in the Russian Federation is the experience of the Republic of Belarus in creating strict centralization in the public administration system in making decisions and monitoring their implementation. At the same time, this circumstance is compensated by a fairly wellfunctioning system of monitoring the effectiveness of the executive bodies with the possible prosecution of guilty officials (up to criminal). 
Fifthly, in the Republic of Belarus, executive authorities create the conditions and facilitate the exercise by citizens of their constitutionally and legislatively fixed rights, freedoms and interests.

President of A.G. Lukashenko in the U.S. and many Western European countries, political and public figures often call to as "the last dictator in Europe", "fascist" (thereby trying to challenge the legitimacy of the executive branch in the Republic, emphasizing its totalitarian and antidemocratic character) (Goncharov, Zhilin, 2009), but the growth rate of gross domestic product in the Republic of Belarus from 1994 to 2009, many times higher than similar indicators in the United States and European Union countries, the low level of corruption and crime in the country, citizens' confidence in stability with of his future, these slanderous libels refute. In comparable prices, the gross domestic product of the Republic is up to $1 / 3$ of the US level per capita (Website, 2020). Considering that in the Republic of Belarus the level of property stratification in society is lower than in the USA (5,3 and 17 times, respectively) (Goncharov, Zhilin, 2009), the standard of living of the middle class and the poorest segments of the population in the Republic is comparable to the poorest developed countries in Europe (Portugal and Spain) and is ahead of living standards of a significant part of citizens of other CIS countries.

Sixthly, in the Republic of Belarus, a system has been established to monitor the effectiveness of the activities of executive bodies by assessing the level of their executive discipline. Supervisory authorities analyze the quality of services provided to the public, the level of responsiveness in decision-making by government officials, the degree to which the governing decisions of higher executive authorities and their officials are timely, and their performance. The branches of the economy are analyzed financial and economic performance.

An important role in assessing the effectiveness of the execution of the republican budget, the use of state property, the activities of authorities regulating relations of state property, economic, financial and tax relations, in accordance with Chapter 8 of the Constitution of the Republic of Belarus, belongs to the State Control Committee formed by the head of state (Constitution, 2020a). His powers are much wider than that of his Russian counterpart, the Accounts Chamber of the Russian Federation, in addition, it is not a parliamentary body, but a presidential financial and economic control.

In the system of state administration of the Republic, a tough fight is being waged not only against thieves of budgetary funds (the level of such corruption in the country is only slightly higher than similar figures when the USSR was), but also with officials of executive authorities who are inefficiently using budgetary funds and state property. Moreover, when checking the effectiveness of the work of executive officials in Belarus, the main criteria are the compliance of the costs of maintaining the authority (and its activities in providing public services to the public) with the financial results of such activities (Website, 2020). Unlike the Russian Federation, property confiscation is actively used for such crimes, and those responsible are sentenced to significant sentences.

It seems that the public administration system in PRC is unique and effective for a number of reasons (due to which its positive experience of modernization can be used to optimize the executive system in the Russian Federation):

Firstly, it is a kind of symbiosis of the Soviet socialist and liberal capitalist models of governance. This dualism is also present in the fact that within the framework of the PRC there are two different approaches to the organization and operation of the state power system. So, if the state power of mainland PRC belongs to the people and is exercised in accordance with the Constitution of the People's Republic of China to the All-China Assembly of People's Representatives and local assemblies of people's representatives of various levels (Constitution, 2020b), then the power in the Hong Kong Special Administrative Region (formerly known as Hong Kong) is completely divided into 
legislative values, executive and judicial branches (Basic, 2020) (in connection with this, the slogan "One China - two systems" was popularized). In addition, the public administration system in China has been given a Chinese national and religious flavor, implicated in the Chinese stubbornness, prudence and industriousness (the so-called "socialism with Chinese characteristics") (State, 1988).

Secondly, the strengthening of the vertical of power has allowed China in recent years to demonstrate impressive economic growth, spiritual and moral renewal of the country, refuting the assertions of many liberal ideologists that any civilization is inherent in the stages of formation, development, growth, prosperity, crisis, degradation and decline. They like to bring this argument in support of the fact that Russia, as an old civilization, is entering a stage of decline, and it has no chance of being reborn as a superpower (Toynbee, 1995).

Thirdly, within the framework of the executive vertical of power in the PRC, an effective system has been built to stimulate the activity of public servants, orienting them towards achieving high results in the organization and activities of the state apparatus. This system is based on a complex mechanism of motivation, which combines the optimal ratio of moral and material methods of encouraging employees of government (How, 2001).

Fourthly, a multilevel control over the effectiveness of the activities of state authorities (the so-called performance audit) has been formed in the country, the essence of which is to compare and evaluate the effectiveness of the activities of executive bodies and other organizations in fulfilling public functions, using public resources, and adopting recommendations to improve their work, and its main purpose is to increase the efficiency of public resource management (Tsutsiev, 2007: 41-45; Maksimova, 2011).

Fifthly, impressive successes, the state mechanism in the PRC has achieved in the fight against corruption, embezzlement, theft of socialist property. In particular, according to the judicial authorities of China, tens of thousands of crimes committed by government officials at various levels are identified annually (Supreme, 2020). The guilty parties will be subjected to uniquely harsh criminal penalties related to confiscation of property of convicts, their life imprisonment and execution (in accordance with the criminal law of the People's Republic of China, the bullet used as a result of the death penalty is even paid for at the expense of the property of the executed criminal or the property of his relatives) (Akhmetshin, Akhmetshin, Petukhov, 2000).

Sixthly, the system of mutual checks and balances in the state apparatus of the PRC is extremely tough in nature, when the activity of any authority is subject to careful crosschecks of dozens of other authorities, and these links are subject to constant rotation in order to minimize the formation of corruption communities in the sphere of the state apparatus (How, 2001).

These successes of the power vertical in China are especially visible in a number of areas of government.

First of all, significant achievements are available in China in the field of economic development planning. Thus, according to statistics, the average growth of gross domestic product in the PRC over the past two decades has been more than $9.3 \%$ per year. At the same time, the growth of the revenues of the total budget of the country was carried out even faster, amounting to $11,7 \%$ annually. This suggests that the PRC government system has managed to increase the degree of centralization of gross income and its concentration in the hands of the state, followed by the planned investment of the revenues in the country's economy.

In addition, PRC has accumulated unique experience in countering the theft of state (public) property and the inefficient use of budget funds and state property. In particular, according to American experts, the amount of corrupt income in 2019 in China was 1,9 times less than in the Russian Federation, while the level of China's GDP exceeded Russia's 
GDP by more than 5,5 times at that time. Moreover, the public administration system in the PRC has shown significant results in terms of strengthening the power vertical, increasing executive discipline and the efficient use of budgetary funds. Thus, one unit of state investment in the Chinese economy leads to a 1,7-fold increase in GDP than with similar government investments in the United States, and 5,3-fold than in the Russian Federation.

However, the public administration system in the People's Republic of China has a number of problems and disadvantages:

1) strong social stratification, lack of power among citizens with significant property ("new Chinese"), instability and unrest in the regions where China's national minorities are densely populated, can lead to the loosening of the socialist foundations of the PRC and its "slide" in its political development onto the path of degradation and centrifugal trends in public administration, which the USSR went through at the end of the $80 \mathrm{~s}$ of the last century, with the subsequent collapse or collapse of the country into a number of independent states. In addition, a certain danger is the fact that in China the process of forming a single Chinese nation is still under development, intensely undermined by Western intelligence agencies and the growing influence of Western culture on the broad masses of Chinese society.

2) Despite the severe suppression of corruption, cronyism, embezzlement in the system of the state apparatus of the PRC, in the opinion of the Supreme Court of the People's Republic of China, the state is experiencing a rapid and uncontrolled growth of corruption, which poses a real danger not only to ensure the progressive growth of the Chinese economy, but also undermines the moral-ethical, legal and moral basis of the organization of power in the country (Supreme, 2020).

3) In addition, many years of flirting, and sometimes direct custody by the top of the state apparatus and special services of the PRC of Chinese organized crime outside the Celestial Empire, in order to achieve various political and economic goals (in particular, ensuring control of financial and production assets abroad, changing the ethnocultural balance in a number of countries strategically important to strengthen the influence of China in the Asia-Pacific region due to the increased migration of the Chinese population) in fact led to incomprehensible interactions and the merging of the state and party apparatus, "the Chinese triads", the new Chinese bourgeoisie, as well as industrialists and financiers outside China. All of this may well serve as a real "fifth column" during the conduct of a comprador revolution in the country with the filing of the West and a regime change (Andreeva, Titova, 2001).

4) The great danger in modern China is the increased dependence of political stability in the country on the dynamics of its economic growth. Launched from the filing of the state and party apparatus, the global breakdown of the economic structure and economy of the PRC led to massive internal migration of rural residents to cities. In addition, millions of citizens are already accustomed to the constant and sustainable development of living standards. A fall in the Chinese economy, and in part even a slowdown in economic growth, may reveal a huge number of management problems fraught with serious political cataclysms.

5) A significant danger to the political future of the PRC is also a growing technological gap between China and the United States and European Union countries. Moreover, in the opinion of a number of leading economists, this is not only about the technological simple $\mathrm{PRC}$, its inability to scientific breakthrough in the military-industrial complex and the qualitative renewal of the structure and combat effectiveness of the Armed Forces. The PRC does not have new technologies for global modeling of social processes (Personal, 2020).

To eliminate these shortcomings in the PRC public administration system, a number of consecutive modernization measures should be carried out: 
a) First of all, it is necessary to build a system that ensures a constant and steady fight against corruption, which should be led by the frequent rotation of managerial personnel in the system of the state apparatus, as well as a change in the modern approach to staffing the All-China Assembly of People's Representatives and local assemblies of People's Representatives of various levels (through elections at the place of residence of voters) (Legal, 2003) for the election of deputies at their place of work (the USSR had a similar experience in forming representative bodies of power before the adoption of the new Constitution of 1936), which will bring democracy to the electoral process and strengthen power from any attempts at collapse and counter-revolution.

b) Strengthening the effectiveness of the public administration system in the PRC will also be facilitated by a decrease in social tension in society, an increase in the property welfare of citizens, and an audit of the large fortunes of the "new Chinese" regarding the legality of their formation. This will allow, on the one hand, to identify and punish persons who have made huge fortunes in violation of the law, and on the other hand, will significantly reduce the property motivation of corrupt officials.

c) Much attention should be paid to the country's leadership in the phased and complete elimination of the "Chinese triads", a kind of Chinese "Trojan horse" that can destroy Chinese nationally oriented statehood.

d) At a significant pace and in a minimum period of time, it is necessary to reorient the capacities of the Chinese economy to the domestic market (which has already been actively undertaken by the country's leadership since the beginning of the global economic crisis). On the one hand, this will ensure complete independence of the political decisions of the PRC leadership from economic constellations in world markets, and on the other hand, it will undermine the economic well-being of Western countries by reducing cheap Chinese exports.

e) In the PRC public administration system, the requirements for the level of executive discipline (especially at the lower levels) should be tightened, providing a single comprehensive audit of the performance of the state apparatus and its employees. For this, it is necessary to modernize the system of state, popular and party control, giving the newly formed bodies wide powers to combat corruption, especially in the ranks of party, Soviet bodies and within the special services (Ogneva, Chubanov, 2006: 79-81).

It seems that in the process of optimizing the system of executive power in the Russian Federation, the positive experience of the development of the public administration system in the PRC can be used:

Firstly, in terms of building an effective system for evaluating and monitoring the performance of executive bodies and their officials, especially in terms of using budget funds and state (municipal) property.

Secondly, in the field of planning the economic development of the state, attracting investments, modernizing the economy, as well as effectively investing at the expense of state and municipal budgets.

Thirdly, in terms of building an effective system to combat corruption, embezzlement and cronyism, which includes both measures to tighten responsibility for public servants who have committed malfeasance, and to create a mechanism to stimulate lawful behavior of employees.

Fourth, in the sphere of building an effective dialogue with society and business in order to stimulate entrepreneurial activity of citizens.

However, one should beware of blindly copying the Chinese experience of optimizing the public administration system for several reasons:

1) Due to the fundamental difference in a number of principles of the organization and activities of state authorities in the Russian Federation and the PRC. For example, in China, the Soviet model of government is still constitutionally fixed, based on the 
sovereignty of the Soviets and the leading governing will of the Chinese Communist Party (Republic, 1989).

2) Due to the weak state and uncompetitiveness of a number of sectors of the Russian economy, errors in state management of the economy cannot be compensated for by the development of the domestic market.

3) Russia, unlike the PRC, does not have such a huge population, a powerful militaryindustrial complex and the Armed forces. Therefore, the openness of the Russian market and entry into the World Trade Organization will only contribute to the degradation of the economy and the collapse of military-industrial technologies.

4) Our country has more unique experience of outstripping growth when the USSR was.

5) Our countries are seriously different in terms of the mentality of citizens. In particular, the Russians are not characterized by the long-term execution of monotonous actions, which is why the stake should be placed on high-tech industries and technologies (Personal, 2020).

At the same time, research shows that the majority of Russian citizens support the use of positive foreign experience in organizing the executive power system in legal reforms: (Goncharov et all., 2020b, 93-106)

Table 1. Do you support the use of foreign experience in reforming the executive power system in Russia.

\begin{tabular}{|c|c|c|c|}
\hline $\begin{array}{c}\text { Age categories of } \\
\text { Russian citizens }\end{array}$ & $\begin{array}{c}\text { Yes, I support it (in } \\
\text { \% of the total } \\
\text { number) }\end{array}$ & $\begin{array}{c}\text { No, I don't support it } \\
\text { (in \%o of the total } \\
\text { number) }\end{array}$ & $\begin{array}{c}\text { I don't know, I'm } \\
\text { undecided (in \% of } \\
\text { the total number) }\end{array}$ \\
\hline 18-30 years old & 45 & 48 & 7 \\
\hline $31-40$ years old & 44 & 46 & 10 \\
\hline $41-50$ years old & 42 & 47 & 11 \\
\hline 51-60 years old & 46 & 44 & 10 \\
\hline 61 years and older & 47 & 42 & 11 \\
\hline
\end{tabular}

\section{Conclusions}

In the process of optimizing the executive power system in the Russian Federation, it is necessary to use foreign positive experience in the formation and functioning of government bodies (executive power). However, this experience should be evaluated according to a number of criteria: a) the presence of a state ideology in the country and its compliance with the prospects for maintaining and developing statehood, state sovereignty, independence and territorial integrity; b) the ability of the executive power system to ensure the progressive development of the state, to create conditions for citizens of the state to exercise their constitutionally and legislatively fixed rights, freedoms and interests; c) independence and democracy of the executive branch; d) its sustainability and effectiveness in spending budget funds and providing public services to the population (the main indicator of this is the achievement of a high level of executive discipline); e) the degree of structure of the executive power system and the availability of the statutory foundations of its organization and activities; f) the existence of criteria and a mechanism for evaluating and self-evaluating the effectiveness and efficiency of the organization and activities.

\section{References}

1. H.M.Akhmetshin, N.H.Akhmetshin, A.A. Petukhov, Modern criminal legislation of the PRC (Moscow, 2000)

2. G. Andreeva, T. Titova, Bulletin of the Institute of CIS countries 42 (2001) 
3. S.A. Avakyan, Journal of the Belarusian State University. Law 3, 18-21 (2019)

4. Basic law of the Hong Kong Special administrative region of the people's Republic of China: adopted in 1990 by the NPC session (2020) http://www.xinhuanet.com

5. V.E. Chirkin, State and law 8, 65-73 (1995)

6. Constitution of the Republic of Belarus of 1994 (Minsk, 2020)

7. Constitution of the people's Republic of China of December 4, 1982 (in the fifth edition of 2004) (2020) http://www.xinhuanet.com

8. Y.A. Dmitriev, V.V. Komarova, Law and life 7, 52-56 (1995)

9. V.V. Goncharov, Journal of foreign law and comparative law 5, 104-107 (2014)

10. V.V. Goncharov, Modern law 3, 127-131 (2011)

11. V.V. Goncharov, S.M. Zhilin, Theoretical and methodological foundations of the organization and activities of the Institute of the President in the Russian Federation. Monograph (Krasnodar, 2009)

12. V. Goncharov, J. Zalesny, S. Balashenko, G. Vasilevich, A. Pukhov, Wisdom 16(3), 78-90 (2020) https://doi.org/10.24234/wisdom.v16i3.332

13. V. Goncharov, J. Zalesny, S. Balashenko, G. Vasilevich, A. Pukhov, Wisdom 15(2), 93-106 (2020) https://doi.org/10.24234/wisdom.v15i2.333

14. How China is governed: the Evolution of China's power structures in the 80-90s of the XX century (Moscow, 2001)

15. S.A. Kalinin, Journal of the Belarusian State University. Law 3, 14-23 (2020)

16. T.M. Kiseleva, Journal of the Belarusian State University. Law 3, 61-69 (2018)

17. V.V. Komarova, Legislation and Economics 5, 5-10 (2006)

18. Legal systems of the world: an Encyclopedic reference (NORMA Publishing House, Moscow, 2003)

19. A.G. Lukashenko, On the state of ideological work and measures to improve it: materials of the permanent seminar of senior officials of Republican and local state bodies (Minsk, 2003)

20. O.O. Maksimova, Constitutional and legal status of the head of state in China: abstract of the thesis of the candidate of legal sciences (Moscow, 2011)

21. T.S. Maslovskaya, The Institute of presidency in the Republic of Belarus: author's abstract of thesis of candidate of legal sciences (Minsk, 2004)

22. T.S. Maslovskaya, Journal of the Belarusian State University. Law 3, 46-52 (2020)

23. E.V. Matusevich, State ideology in the system of national values. Ideology of the Belarusian state: problems of theory and practice: materials of the scientific conference (Minsk, 1998)

24. Y.F. Moros, V. Goncharov, Wisdom 15(2), 114-128 https://doi.org/10.24234/wisdom.v15i2.354

25. V.A. Nechkin, Constitutional and municipal law 9, 52-55 (2014)

26. I.A. Ogneva, A.C. Chubanov, Constitutional reforms: Russia and China. Modern law 3, 79-81 (2006)

27. S.G. Parechina, Belarusian Duma 10, 22-28 (2002)

28. Personal page of Mikhail Delyagin (2020) http://www.delyagin.ru 
29. Report of the President of the Republic of Belarus Alexander Lukashenko at the second all-Belarusian people's Assembly on 18.05.2001 (2020) http://www.president.gov.by/press18819.html\#doc

30. Republic of China. Legislative acts 1984-1988 (Moscow, 1989)

31. Research of the INDEM Foundation "Diagnostics of corruption growth 2005" (Moscow, 2006)

32. State system of the people's Republic of China (Moscow, 1988)

33. Supreme court of the people's Republic of China: China's Executive branch is subject to corruption (2020) http: //vz.ru//news/2009/ 10/29/343015.html

34. A. Toynbee, Civilization before the court of history: a collection (Moscow, 1995)

35. M. Tsutsiev, Budget 7, 41-45 (2007)

36. Website of the President of the Republic of Belarus (2020) http://www.president.gov.by

37. G.A. Vasilevich, Republic of Belarus. Journal of Russian law 7, 22-26 (2012)

38. G.A. Vasilevich, A.A. Kashirkina, A.N. Morozov, Journal of the Belarusian State University. Law 2, 85-92 (2019)

39. J. Zalesny, V. Goncharov, Future Human Image 12, 129-142 (2019) https://doi.org/110.29202/fhi/12/12

40. J. Zalesny, V. Goncharov, M. Savchenko, Wisdom 2(13), 51-61 (2019)

41. J. Zalesny, V. Goncharov, Journal of Legal, Ethical and Regulatory Issues 23(2), 1-6 (2020)

42. J. Zalesny, V. Goncharov, Journal of Legal, Ethical and Regulatory Issues 25(5), 1-10 (2020) 